\title{
Lessons About Cash And Manager Priorities
}

Donald Mong, Slippery Rock University, USA

\begin{abstract}
Experienced managers know that cash affects virtually every aspect of a company's strategy and operations. Business students and new managers, however, sometimes lose sight of the importance of cash amidst the details of accrual-based accounting courses, formula-based finance courses, and production-based management courses. We therefore use recent international research to reinforce practical lessons about cash and manager priorities. In particular, we examine why managers must focus on cash, how managers must balance cash with accruals in maximizing returns to investors, and how managers must cope with differing accounting priorities in obtaining needed information about cash.
\end{abstract}

Keywords: Cash; Manager; Priorities; Accounting; Accrual

\section{INTRODUCTION}

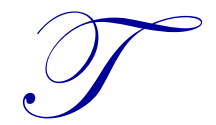

he credit crunch of the Great Recession of 2007 focused attention on the importance of cash. We saw first-hand how little time managers had to turn other assets into cash or have their companies forced out of business. As a result, Hawkes (2012) estimates that Eurozone and American companies now carry 3.8 trillion pounds in excess cash. Managers seem willing to pay unnecessary interest and lose investment opportunities in order to do so. Hawkes characterizes this behavior as precautionary against being unable to obtain future credit, but acknowledges that even managers of credit-rich companies are behaving in the same way. Why, then, is cash so important to these managers, and what can we learn about managerial priorities by studying it?

\section{THE IMPORTANCE OF CASH TO MANAGERS}

Mong (2011) explored the importance of cash from the perspectives of companies, investors, and accountants, concluding that a company's cash flows could reveal its strategies and functions. As we now explore the importance of cash from the perspective of everyday managers, we begin with the entrepreneurial authors upon whom Mong built. Hutchinson (1999) found that entrepreneurial companies flourished far more from the value of cash flows to their owner-managers than from the profits that those companies booked. Opiela (2006) identified cash flows as the single most important factor in the success or failure of entrepreneurial companies. Jacobides and Winter (2007) took a more theoretical look at the importance of cash flows, determining that the need for cash was so great that entrepreneurial companies would occupy only the narrow parts of value chains where they could maximize returns on available cash, rather than the broader parts of chains where their innovations might add economically.

Cash is clearly valuable to entrepreneurial companies, but Bates, Kahle, and Stulz (2009) expanded its importance to non-entrepreneurial companies too. Those researchers found that the cash-to-assets ratios of all United States corporations had more than doubled between 1980 and 2006 and predicted that falling inventories, falling capital expenditures, and increasing research \& development expenses would only heighten the importance of cash. In particular, Bates, Kahle, and Stulz emphasized that higher research and development expenses of corporations would have to be self-financed because lower inventories and fewer capital assets would reduce collateral for loans. Like Hawkes (2012), Bates, Kahle, and Stulz found precautionary cash holding among all sizes of companies. 
Cash is thus important to both entrepreneurial companies and established corporations at the strategic level, but what about at the operating level? Three recent teams of researchers explored three very diverse ways in which cash affected operations managers. Pi-Fang and Miao-Hsueh (2006) showed how traditional cost accounting systems led operating managers to focus mostly on reducing costs within each department, rather than on maximizing cash or profits. As a result, the most efficient managers often produced far more goods in their departments than could be absorbed in downstream departments of the company. The resulting bottlenecks of unnecessary work-in-progress tied up valuable cash and lowered overall profits. Pi-Fang and Miao-Hsueh urged managers to broadly redefine productivity as anything that brought the overall company closer to its goal of making profits, rather than as only those things that increased production efficiency or quality within a given department.

Dasgupta, Noe, and Wang (2011) asked what companies would do when they were able to generate additional cash inflows, and the answer was not encouraging for the resources available to operating departments. Studying Compustat manufacturing companies between 1971 and 2006, Dasgupta, Noe, and Wang found that the overwhelming tendency was to use the additional cash to decrease outstanding debt and increase cash holdings, rather than to engage in new investment in operations.

That finding was particularly distressing in light of the work of Foo Li and Zailani (2012). Those authors studied 202 Malaysian manufacturing companies and found that financial flows affected supply-chain performance far more significantly than material flows and information flows did. Since operating managers had traditionally focused on the logistics of the material and information flows, Foo Li and Zailani urged them to broaden their focus into financial flows. Foo Li and Zailani's definition of financial flows included credit terms, payment schedules, consignment, and titles, a rather broad definition of cash. Nevertheless, the authors stressed that cash flow efficiency could be increased to complement supply chain strategy, particularly in an increasingly world based economy.

Our first lesson, then, is simply that managers must focus on cash regardless of whether those managers work for entrepreneurial companies or established corporations and regardless of whether those managers work at strategic or operating levels.

\section{WHY CASH FLOWS ARE MORE VALUABLE THAN ACCRUALS}

Cash is valuable, but flows of that cash are not always easy to identify. The problem lies with accounting systems. Smaller entrepreneurial companies that use cash-based accounting systems have relatively little difficulty following their cash. Cash-based accounting systems, of course, recognize such things as income and expenses only when the cash for those items is actually received or paid out. However, larger corporations use accrual-based accounting systems, in part because American tax regulations force them to do so. With accrual-based accounting systems, items like income and expenses are recognized earlier, such as when a sale is made. However, cash from those accruals might not flow until much later, such as when customer payment for the sale is received. Accruals, then, are essentially managerial estimates of how much cash will come in, go out, or be moved within a company at some point in the future.

Houge and Loughran (2000) noted that a company's earnings were the sum of its current cash flows and accruals. The researchers sought to determine whether the cash component of those earning, the accrual component, or the overall earnings themselves produced the greatest returns to investors. Just as Sloan (1996) had predicted, empirical research confirmed that the greatest returns came from the cash flows. Houge and Loughran (2000) believed this phenomenon to be quite logical since established economic theory calculated the value of any asset at the sum of its streams of cash flows, discounted for the length of time before each of those cash flows occurred. Thus, current cash flows were far more valuable to investors than future cash flows that might result from accruals.

Shivakumar's (2006) econometric work led him to similar conclusions. Shivakumar conducted rigorous econometric testing of all domestic NYSE/AMEX and NASDAQ stocks between 1979 and 1999 to see what effect unexpected cash flows and unexpected accruals had had on stock prices. Again, the cash flows affected the prices in much greater ways than accruals did. For Shivakumar, the econometrics confirmed what a number of other researchers (Ali, 1994; Pfeiffer et al., 1998; Barth et al., 1999) had been finding - a company's cash flows were indeed driving its attractiveness to investors. 
Tuch and O'Sullivan (2007) looked at that attractiveness when the investor was another company, rather than an individual. Tuch and O'Sullivan asked if there was a difference in expectations for the future performance of acquisitions that had been purchased with cash versus those that had been purchased with stock. In essence, the researchers were asking if the investors (the acquiring companies) demanded greater returns when the investors had had to part with actual cash for the acquisition. The answer was a resounding yes. That answer makes sense to this author, for issuing stock can be thought of as another type of accrual. The issuing company will only need to part with actual cash on that accrual when it later pays dividends on the stock.

Our second lesson is thus that managers should focus more on producing cash flows than on booking accruals. Accruals are certainly valuable in representing future cash flows from long-term projects, but not nearly as valuable as current cash flows are.

\section{WHY CASH IS MOST VALUABLE WHEN FLOWING TO THE INVESTOR}

In 2008, Dechow, Richardson, and Sloan determined that prior research had firmly established the superior persistence (sustainability) of cash over accruals. Persistence was an accounting term that meant that companies with earnings composed of more cash and fewer accruals could replicate those earnings over longer periods of time than companies with earnings composed of the reverse. Dechow, Richardson, and Sloan explored whether the ways in which companies utilized their cash further affected the quality of their earnings. After examining 150,000 firmyears between 1950 and 2003, the researchers found that the highest quality earnings came when companies paid that cash out to investors, rather than reinvesting it in the company.

Even with some American tax consequences, dividends were the most immediate payment of that cash. The problem was that Fama and French (2005) showed a steep decline in dividend-paying companies between 1978 and 1998. However, Chahyadi and Salas (2010) then undertook a deeper quantitative analysis of Compustat data to find why. Chahyadi and Salas determined that $76 \%$ of the decline in dividend payments could be attributed to changes in company profiles. Prior researchers had determined that younger companies with less profit, more growth opportunities, and more debt were less likely to pay dividends, and those characteristics described the 1998 companies. However, many of the 1998 companies were now substituting share repurchases for dividend payments as the preferred way of flowing cash back to investors. When those share-repurchase companies were added to the dividend-paying companies, Chahyadi and Salas found that overall 1998 companies were actually more likely than their 1978 counterparts to return cash to investors.

Tong and Bin (2011) asked whether companies that paid dividends had higher qualities of earnings per se than companies that did not pay dividends. An analysis of 10,661 company years between 1993 and 2004 showed that dividend-paying companies did indeed have more valuable earnings overall than non-dividend-paying companies. In particular, those dividend payers had lower discretionary accruals and stronger relationships between booked accruals and resulting cash flows than the non-dividend-payers. Moreover, the higher the dividends that were paid, the better that the preceding results were.

Tong and Bin (2011) commented that high, regular dividend payments resulted in fewer owner/manager agency conflicts by restricting the discretionary cash left for managers and by ensuring that the company had true cash flows to sustain future dividends. It is interesting to compare that result with the reduction in owner/manager agency conflicts attributed much earlier by Hutchinson (1999) to entrepreneurial companies. Tong and Bin also noted that their research had been unable to determine whether dividend payments alone or share repurchases by the same companies were the primary drivers of the positive results obtained. Insomuch as both dividends and share repurchases flow cash to investors, the point for this article is the same: Investors value cash!

Our third lesson, then, is that managers should focus most on returning cash to investors. Since managers must obviously re-invest significant cash in the company in order to not jeopardize future operations, this third lesson only heightens the importance of the previous lesson, which was to maximize overall cash flows. 


\section{WHY CASH IS HARDER TO MANIPULATE THAN ACCRUALS ARE}

Managers, of course, are not above manipulating financial statements to make investor returns appear more or less likely in a given period. Some manipulation is well intentioned. Lee (2006) introduced the big-bath hypothesis by claiming that, when companies had to substantially reduce dividends, managers used discretionary accruals to make financial statements appear to be as bad as possible. The tactic could be used both to explain to investors why were not receiving dividends in the current period and to set the stage for rapid earnings recovery in future periods. With poor-quality accruals written off in the big bath, remaining accruals were much more likely to translate into higher cash flows in those subsequent periods, ultimately benefitting investors.

Al-Moghaiwli (2010), however, studied a more blatant form of earnings manipulation in Saudi Arabia. Government policies there were decreasing subsidies to private companies and mandating replacement of lower-paid foreign workers with higher-paid Saudi citizens, but delaying those changes for companies with lower earnings. Not surprisingly, Al-Moghaiwli found considerable earnings manipulation through discretionary accruals to show those lower earnings. He noted that, four years before his own study, Alsehali (2006) had found managers using those same discretionary accruals in reverse when they wanted to attain higher earnings benchmarks.

Krishnan, Yuan, and Wanli (2011) found that such manipulation of earnings could be substantially lessened by appointing a lawyer to the company's audit committee. In fact, Krishnan, Yuan, and Wanli found that having a lawyer on that committee produced far better results than having an accountant on the committee. The researchers were unable to determine exactly why the phenomenon occurred. We thus do not know whether the lawyers were directly chilling managers' use of discretionary accruals through their other duties as company directors or just helping the audit committee to select better auditors, who would themselves chill the manipulative use of discretionary accruals.

While harder to manipulate than accruals, cash still can be manipulated. Wuchun, Ling Lei, and Mikhail (2011) found that one incentive for cash manipulation actually resulted from auditors previously restricting the use of discretionary accruals. Without those discretionary accruals as tools to boost current overall earnings, managers turned to cash manipulation techniques like delaying discretionary payments until future years. Wuchun, Ling Lei, and Mikhail speculated, but did not attempt to prove that cash flow manipulation could potentially be more detrimental to investors than accruals manipulation, since current cash flows had more effect than accruals on future cash flows and firm value. Additionally, the authors noted that auditors could not disallow management decisions about cash as easily as they could disallow decisions about discretionary accruals. Nevertheless, Wuchun, Ling Lei, and Mikhail advised companies to rotate auditors regularly to keep sharper eyes on cash flow manipulation.

Lian Fen (2012) too documented cash flow manipulation, this time by shifting the classifications and timing of certain cash flows from operations (CFO's). Lian Fen found the highest incentives for managers to manipulate cash came when companies were in financial distress, in danger of credit-rating downgrades, unlikely to meet analyst forecasts, or needing to upgrade quality of earnings. Nevertheless, Lian Fen concluded that it was much harder for managers to manipulate CFO's, which required actual current cash, than it was to manipulate accruals, which required only managerial estimates of future cash.

Our fourth lesson, then, is that encouraging managers to focus on cash flows lessens the chances of manipulation and reduces owner/manager agency conflicts.

\section{WHY ACCOUNTANTS STILL PREFER ACCRUALS}

We have seen that cash is both more valuable and harder to manipulate than accruals. It would thus seem that both investors and managers would be best served by financial statements that are cash-focused. Nevertheless, most accountants continue to prefer accrual-focused financial statements. Why is this so?

Schipper and Vincent (2003) explained the position of the Financial Accounting Standards Board (FASB), which formulates United States accounting and auditing standards. Schipper was a member of the FASB and had observed efforts to make its standards more relevant to non-accountants. He and Vincent felt that those efforts had 
given managers too much freedom to manipulate the relative levels of cash and accruals. The authors thus opined that using the cash component alone to measure the quality of earnings was "not necessarily consistent with a representational faithfulness criterion." As a result, Schipper and Vincent believed that the (FASB) was unlikely to accept any new standards that judged the quality of company earnings primarily on the cash component of those earnings.

Instead, Schipper and Vincent (2003) preferred to continue the accountant's historical focus on accrualbased Hicksian income, the total change in the company's wealth from one reporting period to the next. The authors defined Hicksian income as the net change in the economic assets of a company over the reporting period, plus the dividends that the company paid to its shareholders during that reporting period. Schipper and Vincent believed that this focus led to more accurate representation of the persistence (sustainability) of overall earnings, the predictive ability of those earnings, and the variability of the earnings. Nevertheless, the authors acknowledged that cash was indeed more objective than accruals. Schipper and Vincent acknowledged that part of their reluctance to focus more on cash came from difficulties in categorizing it on the traditional statement of cash flows.

Schipper and Vincent (2003) further acknowledged a number of commentators pushing for greater cash focus in financial statements. We shall see some of those commentators in the remaining sections of this article as we explore the interplay between the manager's needs for cash and the accountant's preference for accruals. For now, however, we leave our fifth lesson with Schipper and Vincent's summary of the FASB position: Accounts prefer accruals, and managers must cope with that preference.

\section{HOW ANALYSTS CAN SOMETIMES HELP MANAGERS TO FIND CASH}

One way for managers to cope with accountant preferences is to engage financial analysts to find cash in accrual-focused financial statements. Yu (2008) noted that almost one-half of the ratios applied to analyze financial statements focused on cash, particularly cash flow, cash position, and liquidity. That same year, Dechow, Richardson, \& Sloan (2008) affirmed the superior persistence (sustainability) of cash over accruals. Recent researchers have sought to develop a number of analytical models to predict future cash performances of companies from current accrual-based financial statements.

Barth, Cram, and Nelson (2001) used the work of Dechow, Kothari, and Watts (1998) to develop a model for predicting a company's future earnings by disintegrating accruals into sub-categories, including cash flows. Malicrida et al. (2010) then applied that model to 29 Brazilian companies, finding once again that current cash flows were better predictors of future earnings than current accruals were. Interestingly, however, Malicrida et al. concluded that the model's use of both current cash flows and current accruals together produced better predictions than cash flows alone could.

Hafzalla, Lundholm, and Van Winkle (2011) proposed an alternate model based on percent accruals. Drawing from Sloan (1996), Hafzalla, Lundholm, and Van Winkle's model sought to replace the accruals-to-totalassets ratio commonly used by analysts with an accruals-to-income ratio. The researchers believed that their model could better identify companies whose earnings came more from cash and less from accruals.

Dickinson's (2011) model concentrated on the traditional statement of cash flows. This model sought to predict future profits based on stages of company life cycles. Most life-cycle models focused on sales growth, but Dickinson found that focusing on cash flows uncovered hidden profit potentials in mature companies. In other words, the mature firms would produce better-than-expected cash for several years after sales growth had stagnated. Dickinson asserted that her model could be obtained through "parsimonious" calculations to the currently used statement of cash flows.

Beisland's (2011) model focused instead on income statements and was developed through a study of Norwegian companies. Beisland believed those companies to be good proxies for the larger pool of worldwide companies because Norway had strong investor protection laws and accounting standards nearly identical to United States standards. He characterized prior literature as having determined that financial statements were of limited values to investors seeking to predict future cash flows and future company values, but believed that much deeper regression analysis of income statements could produce useful results. 
Biesland (2011) might be right about the deep regression, but financial statements should be useful on their face and not merely be raw material for deep regression. Jones and Smith (2011) urged that more disaggregated earnings information be required on financial statements. Jones and Smith found that different types of income had different predictive values for future cash flows, but that most readers of financial statements would not recognize the differences substantial guidance through disaggregation. Boulton, Smart, and Zutter (2011) then found that hard-to-understand financial statements were more than just an inconvenience. An analysis of 10783 IPO's from 37 countries showed that investors were willing to pay significantly more for the stock of companies with understandable financial statements than for the stock of companies with hard-to-understand financial statements.

Our sixth lesson is thus that financial analysts can sometimes help managers to find cash in accrual-focused financial statements, but cannot fully address managers' needs.

\section{WHY MANAGERS NEED DIRECT, CASH-FOCUSED FINANCIAL STATEMENTS}

Most managers, especially those at the operating level, still depend on accountants for the financial statements which the managers must use. Financial analysis of those statements is costly, and few managers have time to wait for it. Managers need direct, cash-focused accounting statements. Unfortunately, there has been little progress since Mong's (2011) summary of cash-focused accounting advocacy. We draw from it here to provide students and new managers with at least some practical tools for finding and managing cash.

Advocacy of cash-focused accounting started at the strategic level when Govindarajan and Shank (1986) called cash sufficiency the missing link in strategic planning. Burger and Hamman (1999) then introduced the cashflow sustainable growth rate to tie allowable growth to the maintenance of acceptable cash balances in companies. Advocacy of cash-focused accounting spread when Vent and Cocco (1996) found that even accounting students had trouble understanding the statement of cash flows. Since the statement of cash flows was the primary tool for identifying cash within accrual-based accounting systems, the quest for simpler, more cash-focused financial statements began.

Dechow and Dichev (2002) advanced that quest when they proposed a more direct approach to measuring the relationship between cash and accruals in a company's overall earnings. Even Schipper and Vincent (2003), spokespersons for the Financial Accounting Standards Board's (FASB's) reluctance to tie quality of earnings to cash, believed that Dechow's and Dichev's approach was faithful to their own preferred Hicksian approach. Schipper and Vincent's endorsement was limited, however, by insisting on continued use of the traditional statement of cash flows and by noting the difficulties of directly categorizing different cash flows on that traditional statement.

Hewitt (2009), however, found that both professional analysts and non-professional investors had trouble even separating cash flows from accruals on the traditional statement of cash flows. Hewitt too believed that this difficulty stemmed from the indirect method by which the Financial Accounting Standards Board (FASB) required the statement of cash flows to be prepared and presented. Nevertheless, he was hopeful that work by the Financial Statement Presentation Project and discussions by the FASB would produce major revisions to those standards. Hewitt quoted one FASB chair as saying that the proposed revisions were intended to have the income statement and the statement of cash flows be used in two distinct ways. The former could continue to be accrual-based with the latter becoming more directly cash-based.

While the FASB debates possible changes to traditional statements, Ohlson and Aier (2009) have developed a more direct method of producing accrual-free accounting statements. Ohlson and Aier focus on the income statement and propose modified-cash accounting (MCA) method of producing that statement. The MCA income statement is to be based on defining cash more broadly than the FASB's Generally Accepted Accounting Practices (GAAP) do. The MCA income statement is to rely on common-sense judgments about whether or not each of its own line items is relatively liquid. Ohlson and Aier emphasize that their MCA income statement could not be derived from the currently used GAAP statement of cash flows. While the authors believe that their approach has advantages over FASB proposals in broadening the definition of cash and lessening line-item adjustments, they acknowledge both proposals are similar in being directly derived from cash sales and in having easy-to-use bottom lines. 
Hopefully, such emerging cash-based accounting trends will continue, for they should make following a company's cash flows easier for managers and other non-accountants. In the meantime, the business students and new managers toward whom the lessons in this article are targeted will have little choice but to cope with current GAAP accounting statements and to ask their bosses to urge company accountants to incorporate at least some cashfocused accounting into internal accounting statements.

\section{CONCLUSION}

The lessons of this article are certainly not an exhaustive study of cash. We leave that study to our financial and, to some extent, accounting colleagues. Our purpose here has simply been to reinforce practical lessons for business students and new managers about how cash affects managerial priorities. Once again, our seven lessons are:

1. Managers should focus on cash, regardless of whether those managers work for entrepreneurial companies or established corporations, and regardless of whether those managers work at strategic or operating levels.

2. Managers should focus more on producing cash flows than on booking accruals.

3. Managers should focus on returning cash to investors.

4. Managers should focus on cash because it is harder to manipulate and lessens owner/manager agency conflicts.

5. Accountants still prefer accruals, and managers must cope with that preference.

6. Financial analysts can sometimes help managers to find cash in accrual-based financial statements, but analysts cannot completely address managers' needs.

7. Managers need direct, cash-focused financial statements, and managers need to actively advocate for those statements.

\section{AUTHOR INFORMATION}

Donald Mong is an Assistant Professor of Law at Slippery Rock University of Pennsylvania. His research interests include a variety of legal, entrepreneurial, and pedagogical topics. E-mail: $\underline{\text { donald.mong@ @ sru.edu }}$

\section{REFERENCES}

1. Al-Moghaiwli, M. (2010). The Management of Reported Earnings to Avoid Political Costs: A Study of Saudi Arabian Firms. International Journal of Management, 27( 2), 254-266.

2. Barth, M., Cram, D., \& Nelson, K. (2001). Accruals and the Prediction of Future Cash Flows. Accounting Review, 76(1), 27-58.

3. Bates, T., Kahle, K., \& Stulz, R. (2009). Why Do U.S. Firms Hold So Much More Cash than They Used To? Journal of Finance, 64(5), 1985-2021.

4. Beisland, L. (2011). The Effects of Earnings Variables on Stock Returns among Public Companies in Norway: A Multiple Regression Analysis. International Journal of Management, 28( 3), 773-783.

5. Boulton, T., Smart, S., \& Zutter, C. (2011). Earnings Quality and International IPO Underpricing. Accounting Review, 86(2), 483-505.

6. Burger, J. \& Hamman, W. (1999). The Relationship between the Accounting Sustainable Growth Rate and the Cash Flow Sustainable Growth Rate. South African Journal of Business Management, 30(4), 101.

7. Chahyadi, C, \& Salas J. (2012). Not Paying Dividends? A Decomposition of the Decline in Dividend Payers. Journal of Economics \& Finance, 36(2), 443-462.

8. Dasgupta, S., Noe, T., \& Wang, Z. (2011). Where Did All the Dollars Go? The Effect of Cash Flows on Capital and Asset Structure. Journal of Financial \& Quantitative Analysis, 46( 5), 1259-1294.

9. Dechow, P., Richardson, S., \& Sloan, R. (2008). The Persistence and Pricing of the Cash Component of Earnings. Journal of Accounting Research, 46(3), 537-566.

10. Dickinson, V. (2011). Cash Flow Patterns as a Proxy for Firm Life Cycle. Accounting Review, 86(6), 19641994.

11. Fama, E. \& French, K. (2005). Disappearing Dividends: Changing Firm Characteristics or Lower Propensity to Pay? Recent Developments in Corporate Finance, 2, 91-131. 
12. Foo Li, L., \& Zailani, S. (2012). Effects of Information, Material and Financial Flows on Supply Chain Performance: A Study of Manufacturing Companies in Malaysia. International Journal Of Management, 29(1), 293-313.

13. Govindarajan, V., \& Shank, J. (1986). Cash Sufficiency: The Missing Link in Strategic Planning. Journal of Business Strategy, 7(1), 88.

14. Hafzalla, N., Lundholm, R., \& Van Winkle, E. (2011). Percent Accruals, Accounting Review, 86(1), 209236.

15. Hawkes, A. (2012). Cash is King. Financial Management, (14719185), 26-29.

16. Hewitt, M. (2009). Improving Investors' Forecast Accuracy when Operating Cash Flows and Accruals Are Differentially Persistent. Accounting Review, 84(6), 1913-1931.

17. Houge, T. \& Loughran, T. (2000). Cash Flow is King? Cognitive Errors by Investors. Journal of Psychology \& Financial Markets, 1(3/4), 161-175.

18. Hutchinson, P. (1999). Small Enterprise: Finance, Ownership and Control. International Journal of Management Reviews, 1(3), 343.

19. Jacobides, M. \& Winter, S. (2007). Entrepreneurship and firm boundaries: The Theory of a Firm. Journal of Management Studies, 44(7), 1213-1241.

20. Jones, D. \& Smith, K. (2011). Comparing the Value Relevance, Predictive Value, and Persistence of Other Comprehensive Income and Special Items. Accounting Review, 86(6), 2047-2073.

21. Krishnan, J., Yuan, W., \& Wanli, Z. (2011). Legal Expertise on Corporate Audit Committees and Financial Reporting Quality. Accounting Review, 86(6), 2099-2130.

22. Lee, P. (2006). The Big Bath Hypothesis: Accruals Management in Response to Dividend Reduction and Omission. International Journal of Management, 23(2) 281-288.

23. Lian Fen, L. (2012). Incentives to Inflate Reported Cash from Operations Using Classification and Timing. Accounting Review, 87(1), 1-33.

24. Malacrida, M., de Lima, G., Fávero, L., \& Lima, I. (2010). An Accounting Accruals Model to Predict Future Operating Cash Flows: Evidence from Brazil. International Journal of Management, 27(3), 562578.

25. Mong, D. (2011). Follow the Cash: Lessons for Capstone Business Courses. Journal of Business \& Economics Research, 9(12), 33-44.

26. Ohlson, J. \& Aier, J. (2009). On the Analysis of Firms' Cash Flows. Contemporary Accounting Research, 26(4), 1091-1114.

27. Opiela, N. (2006). Keeping Small-Business Cash Flow on Track. Journal of Financial Planning, 19(7), 2632.

28. Pi-Fang, H. \& Miao-Hsueh, S. (2005). Using the Theory of Constraints to Improve the Identification and Solution of Managerial Problems. International Journal of Management, 22(3), 415-425.

29. Schipper, K., \& Vincent, L. (2003). Earnings Quality. Accounting Horizons, 17, 97-110.

30. Shivakumar, L. (2006). Accruals, Cash Flows and the Post-Earnings-Announcement Drift. Journal of Business Finance \& Accounting, 33(1/2), 1-25.

31. Sloan, R. (1996). Do Stock Prices Fully Reflect Information in Accruals and Cash Flows about Future Earnings? Accounting Review, 71(3), 289-315.

32. Tong, Y. \& Bin, M. (2011). Are Dividends Associated with the Quality of Earnings? Accounting Horizons, 25(1), 183-205.

33. Tuch, C. \& O'Sullivan, N. (2007). The Impact of Acquisitions on Firm Performance: A Review of the Evidence. International Journal of Management Reviews, 9(2), 141-170.

34. Vent, G., \& Cocco, A. (1996), Teaching the Cash Flows from Operations Section of the Statement of Cash Flows under the Indirect Method: A Conceptual Framework. Journal of Education for Business, 71(6), 344.

35. Wuchun, C., Ling Lei, L., \& Mikhail, P. (2011). Is Enhanced Audit Quality Associated with Greater Real Earnings Management? Accounting Horizons, 25(2), 315-335.

36. Yu, C. (2008). Relationship between Industry Characteristics of Firms and their Financial Statement Presentation Formats: An Empirical Study in the United States. International Journal of Management, 25(1), 69-76. 